\title{
Evaluation of Physico-Functional, Cooking and Textural Quality Characteristics of Foxtail Millet (Setaria italica) Based Vermicelli
}

\author{
Pragya Pandey $^{1 *}$, Usha Malagi ${ }^{1}$, Nirmala Yenagi $^{1}$ and Pushpa Dhami ${ }^{2}$ \\ ${ }^{1}$ Department of Food Science and Nutrition, College of Rural Home Science, \\ University of Agricultural Sciences, Dharwad-580 005, Karnataka, India \\ ${ }^{2}$ Department of Food and Nutrition, College of Home Science, Acharya N. G. Ranga \\ Agricultural University, Hyderabad-500030, Telangana, India \\ *Corresponding author
}

\begin{tabular}{|c|c|}
\hline \multicolumn{2}{|r|}{ A B S T R A C T } \\
\hline & \multirow{5}{*}{$\begin{array}{l}\text { Vermicelli was prepared from composite flour of various combinations of foxtail millet } \\
\text { flour, semolina, black gram flour and fenugreek seed flour and evaluated the influence of } \\
\text { formulations on physical, functional, cooking and organoleptic properties. A novel value } \\
\text { added vermicelli was successfully produced. It was observed as the concentration of } \\
\text { steamed foxtail millet flour was increased the cooking time, cooked volume and cooked } \\
\text { weight was decreased as well as cooking loss was increased while the cooking quality of } \\
\text { developed vermicelli was enhanced by the incorporation of blackgram flour and fenugreek } \\
\text { seed powder. Same trend was observed with respect to textural profile of vermicelli. } \\
\text { Textural profile was improved with the addition of steamed foxtail millet flour and black } \\
\text { gram flour. On the basis of cooking, sensory and texture analysis, vermicelli containing } \\
50 \% \text { foxtail millet flour and } 20 \% \text { black gram flour and } 1 \% \text { fenugreek seed flour resulted in } \\
\text { better quality and nutritious vermicelli. }\end{array}$} \\
\hline & \\
\hline $\begin{array}{l}\text { Foxtail millet, } \\
\text { Vermicelli. }\end{array}$ & \\
\hline Article Info & \\
\hline $\begin{array}{l}\text { Accepted: } \\
\text { 14 September } 2017 \\
\text { Available Online: } \\
10 \text { October } 2017\end{array}$ & \\
\hline
\end{tabular}

\section{Introduction}

Nutritional property of food is the utmost important parameter for maintaining human health and competes physical fitness. Since nutritional well-being is the dynamic force for development of human genetic potential, nutritional quality of food should be taken care for maintaining human health (Radhika et al., 2011). Diversification of food production must be encouraged at national and household level with improved yields and household techniques (Singh and Raghuvanshi, 2012). Some of the highly nutritious agricultural foods are not being used as human foods because of unawareness of people. Millets are one of them. Millets are being used as bird and animal feed. Millet has many nutritional and medical properties reported (Yang et al., 2012). These are neglected and under-utilized crop because of scarce knowledge to people and some other critical problems like lower cooking quality and low bioavailability of nutrients in millets. These problems could be tackled to make millets valuable as food for ensuring food and nutritional security.

Foxtail millet is a potentially tremendous crop but under-explored as compared to cereals. In 
the era of growing divide and problem of nutritional security, these qualities must be harnessed to develop foxtail millet as a novel functional food. In this communication, an attempt has been made to find out the suitability of foxtail millet (FM) in combination with other ingredients (viz. black gram flour and fenugreek seed powder) for the vermicelli making quality. Thus, for the health conscious genre of the present world, minor millet especially foxtail millet is perhaps one more addition to the proliferating list of healthy foods, owing to its nutritional superiority. It is speek time for potential millets like foxtail millet to be included in the daily diet. Foxtail millet has been utilized for formulation of ready to eat items, fermented foods, bakery foods and convenience mixes. Very few researches have been carried out on development of extruded products from foxtail millet and other functional ingredients.

There is a need to increase the consumption of foxtail millet by incorporating into food products like vermicelli, which are liked by all age group people. With the modern people chasing healthy foods and ready to cook items and owing to nutritional superiority of millets, there is a need to develop millet based processed foods such as vermicelli.

Therefore, the present study was taken up to evaluate the physico-functional, cooking and textural quality characteristics of foxtail millet (Setariaitalica) based vermicelli for development of functional value added novel product.

\section{Materials and Methods}

The present study was carried out in the Department of Food Science and Nutrition, Dharwad. Local variety of decorticated foxtail millet, black gram dhal, fenugreek seeds and commercial semolina were procured from the local market. The grains were cleaned manually and stored at ambient conditions for the further investigations.

\section{Physical characteristics of foxtail millet and other ingredients used}

Physical characteristics generally influence the functional and organoleptic characteristics. They were studied using standard procedures.

Seed weight (Balasubramanian and Vishwanathan, 2010)

Counting of 1000 grains was done using seed counter in duplicate for each variety. Each duplicate was weighed in grams to one decimal place.

\section{Seed volume (William et al., 1983)}

Thousand seeds were transferred to a $15 \mathrm{ml}$ measuring cylinder to which $5 \mathrm{ml}$ demineralised water was added using a pipette. Seed volume ( $\mathrm{ml} / \mathrm{seed})$ was calculated as below.

$$
\text { Total Volume - } 5
$$

Seed volume $=$

$$
1000
$$

\section{Bulk density $(\mathrm{g} / \mathrm{ml})$}

Bulk density was determined using the formula

Thousand grain weight (g) Bulk density $(\mathrm{g} / \mathrm{ml})=$

Thousand grain volume (ml)

Flour quality characteristics of foxtail millet and other ingredients

The foxtail millet flour, semolina, black gram dhal flour and fenugreek seed powder were studied for physical and functional properties. 


\section{Physical characteristics of flour}

\section{Volume}

Twenty grams of flour was taken in a measuring cylinder and was tapped 100 times tightly and final volume was recorded.

\section{Density}

Density of flour was determined using the formula

Flour weight (g)

Flour density = -------------

Functional properties of foxtail millet flour and other ingredients

\section{Water absorption of flour}

Twenty grams of flour was kneaded into a normal dough with requisite amount of water and water added measured as absorption capacity and noted down (Austin and Ram, 1971)

\section{Swelling power and percent solubility}

Swelling power and percent solubility was determined according to the method of Schoch (1964). About $500 \mathrm{mg}\left(\mathrm{W}_{1}\right)$ of flour taken in a centrifuge tube and weighed the centrifuged tube with flour $\left(\mathrm{W}_{2}\right)$ and $20 \mathrm{ml}$ (Ve) of distilled water was added. Then it was allowed for 30 minutes in a boiling water bath.

The contents were cooled and centrifuged at $5000 \mathrm{X} \mathrm{g}$ for 10 minutes. The aliquot was transferred to a test tube and was wiped well and again the centrifuge tube was weighed with swelled material $\left(\mathrm{W}_{3}\right)$. Swelling power of semolina per gram was calculated by using the formula.
Swelling power/g $=\frac{\left(\mathrm{W}_{3}-\mathrm{W}_{2}\right) \times 1}{\mathrm{~W}_{1}}$

For percent solubility of semolina the dried moisture dish was weighed $\left(\mathrm{W}_{4}\right)$ and $10 \mathrm{ml}$ of aliquot (Va) was pipette out in to the moisture dish.

Then it was dried at $110^{\circ} \mathrm{C}$ in an oven, cooled in a desiccators and again weighed the moisture dish $\left(\mathrm{W}_{5}\right)$. The percent solubility in the aliquot was calculated by

$$
\% \text { Solubility }=\frac{(\mathrm{W} 5-\mathrm{W} 4) \times \mathrm{Ve} \times 100}{\mathrm{Va} \quad \mathrm{W} 1}
$$

\section{Processing of raw ingredients}

The foxtail millet flour was tried in the treatments in two forms i.e., in unprocessed flour and in processed form. Processing of foxtail millet was carried out as given in Figure 1.

The fenugreek was processed prior to incorporation in the composite mix flour to decrease the bitterness as given in figure 2 .

\section{Formulation of composite mix flour}

Foxtail millet flour, black gram dal flour and fenugreek seed flour were mixed and passed through a 100 mesh sieve to obtain a fine powder. Various blends were prepared by incorporating foxtail millet flour, black gram dal flour and fenugreek seed powder with refined semolina at different proportions as given in Table 1. Vermicelli products were prepared as follows: homogenized flours were mixed with water. The dough was kneaded for required duration and kept for 15-30 minutes. Following this, dough was stretched and extruded and dried (cabinet drier) at $60^{\circ} \mathrm{C}$ for 4 hrs. 


\section{Cooking quality of vermicelli}

\section{Cooking time}

A known quantity of vermicelli were dropped in boiling water and cooking time was noted by pressing the cooked grain between the glass slides and the time taken for disappearance of opaque core of vermicelli strands was taken as cooking time.

\section{Cooked weight and volume}

A $10 \mathrm{~g}$ of vermicelli was taken and cooked in $200 \mathrm{ml}$ of water. Weight of cooked vermicelli was measured by using electronic balance and volume of cooked vermicelli was measured using measuring cylinder.

\section{Bulk density}

Bulk density of cooked vermicelli was determined using the formula,

Cooked weight of vermicelli (g) Bulk density of cooked vermicelli $=$

Cooked volume of vermicelli (ml)

The amount of total solid lost in cooking water (gruel) was determined by cooking $10 \mathrm{~g}$ vermicelli in $200 \mathrm{~mL}$ of water until cooked. The gruel was taken in a Petri dish and oven dried at $110^{\circ} \mathrm{C}$ until its weight became constant. Cooking loss was calculated by taking the difference in the weights and reported on dry basis.

\section{Texture}

Texture was analysed by Texturometer. Vermicelli were subjected to a compression test by using fracture wedge probe attached to an Instron Universal Testing Machine of TAXT. Plus texture analyzer with $5 \mathrm{~kg}$ load cell. Pretest speed of $2.50 \mathrm{~mm} / \mathrm{sec}$, test speed $3.300 \mathrm{~mm} / \mathrm{sec}$ and posttest speed of 10.00 $\mathrm{mm} / \mathrm{sec}$ were maintained. The force required to break the vermicelli was measured to indicate texture (hardness) in terms of grams.

\section{Organoleptic evaluation of developed foxtail millet based vermicelli}

Cooked vermicelli were evaluated for overall acceptability by scoring method using nine point hedonic scale by a panel of $10 \mathrm{semi}$ trained members.

\section{Statistical analysis}

The data collected in triplicate values for all the quality parameters was statistically analyzed. The data was analyzed by using one way ANOVA to test significant difference among different trials tried for development of foxtail millet vermicelli. Data are presented as means and compared by one-way analysis of variance (ANOVA) using SPSS software. Means were compared to test for significant differences $(\mathrm{p}<0.05)$ using the least significant difference statistic.

\section{Results and Discussion}

\section{Physical parameters of millets and pulses}

The maximum thousand grain weight was observed in pearl millet $(11.39 \mathrm{~g} / 100 \mathrm{~g})$ and soybean $(146.03 \mathrm{~g} / 100 \mathrm{~g})$ followed by kodo millet $(2.45 \mathrm{~g} / 100 \mathrm{~g})$, proso millet $(2.43$ $\mathrm{g} / 100 \mathrm{~g})$, little millet $(2.23 \mathrm{~g} / 100 \mathrm{~g})$ and horse gram $(34.25 \mathrm{~g} / 100 \mathrm{~g})$. The maximum seed volume was observed in pearl millet $(6.46 \mathrm{ml})$ and soybean $(110.80 \mathrm{ml})$ followed by proso millet $(2.65 \mathrm{ml})$, kodo millet $(2.15 \mathrm{ml})$, little millet $(1.48 \mathrm{ml})$ and horse gram $(31.70 \mathrm{ml})$. Pearl millet and soybean had the highest bulk density followed by other millets and pulses. The physical parameters like thousand grain weight, seed volume and bulk density were assessed and the results are presented in Table 2. 
The maximum thousand grain weight was observed in pearl millet $(11.39 \mathrm{~g} / 100 \mathrm{~g})$ and soybean $(146.03 \mathrm{~g} / 100 \mathrm{~g})$ followed by kodo millet $(2.45 \mathrm{~g} / 100 \mathrm{~g})$, proso millet (2.43 $\mathrm{g} / 100 \mathrm{~g})$, little millet $(2.23 \mathrm{~g} / 100 \mathrm{~g})$ and horse gram $(34.25 \mathrm{~g} / 100 \mathrm{~g})$. The maximum seed volume was observed in pearl millet $(6.46 \mathrm{ml})$ and soybean $(110.80 \mathrm{ml})$ followed by proso millet $(2.65 \mathrm{ml})$, kodo millet $(2.15 \mathrm{ml})$, little millet $(1.48 \mathrm{ml})$ and horse gram $(31.70 \mathrm{ml})$. Pearl millet and soybean had the highest bulk density followed by other millets and pulses.

Weight $(23.07 \mathrm{~g})$ and volume $(11.30 \mathrm{gm})$ of 1000 black gram dhal was higher than the fenugreek seeds $(16.67 \mathrm{~g}$ and $11.07 \mathrm{ml})$ and foxtail millet $(2.39 \mathrm{~g}$ and $0.85 \mathrm{ml})$ respectively. Whereas, density was higher for foxtail millet $(2.81 \mathrm{~g} / \mathrm{ml})$ compared to black gram dhal $(2.04 \mathrm{~g} / \mathrm{ml})$ and fenugreek seed $(1.51 \mathrm{~g} / \mathrm{ml})$.

Physical and functional characteristics of foxtail millet flour, black gram dhal flour, fenugreek seeds powder and semolina are presented in Table 3. When the volume of the flour per ml was considered, the values were similar with respect to semolina, foxtail millet flour and fenugreek seed powder $(1.04 \mathrm{ml} / \mathrm{g})$. However, the volume of black gram dhal flour was significantly lower $(1.02 \mathrm{ml} / \mathrm{g}$ ) (at $5 \%$ level) compare to the other flours. The density of the different flour used for vermicelli development was found be similar $(0.97 \mathrm{~g} / \mathrm{ml})$.

The water absorption capacity of semolina was found to be significantly higher $(0.8$ $\mathrm{ml} / \mathrm{g})$ than the foxtail millet $(0.50 \mathrm{ml} / \mathrm{g})$ and black gram dhal flour $(0.48 \mathrm{ml} / \mathrm{g})$. The swelling power (per gram) of fenugreek seed powder was highest $(8.91 \%)$ followed by semolina $(8.00 \%)$, foxtail millet $(7.2 \%)$ and least was observed in black gram dhal flour $(5.53 \%)$. These values were found to be highly significant (at $1 \%$ level). The percent solubility was found to be highest for semolina $(30.53 \%)$ followed by foxtail millet flour $(22.36 \%)$ and fenugreek seed powder (26.07\%), however least was found in black gram dhal flour $(21.53 \%)$.

\section{Cooking quality of different trials for vermicelli development}

Table 4 shows the cooking behavior of different vermicelli prepared during the optimization. The cooking quality of all the trails varied significantly. As foxtail millet flour was incorporated (T1, T2 and T3) in the composite mix flour, cooking time increased (8.20 to 8.5) significantly as compared to control $(6.90 \mathrm{~min})$. When steamed foxtail millet flour was incorporated in the samples T4, T5, T6 and T7, the cooking time decreased significantly (5.25 min in sample T7) as compared to vermicelli samples from unprocessed foxtail millet flour (T1, T2 and T3)which ranged from 8.2 to 8.5 minutes. Incorporation of black gram dhal flour into composite mix flour (Sample T4, T5, T6 and T7) further showed a significant decrease in the cooking time as compared to vermicelli from steamed foxtail millet flour (T4, T5, T6 and T7). Addition of fenugreek seed powder in samples (T12, T13 and T14) did not change cooking time significantly. It may be because quantity of fenugreek seed powder was very low in the samples. The maximum time taken for cooking was observed for $\mathrm{T} 1$ and the lowest was observed for T9. The cooking time of foxtail millet vermicelli was lower than control because semolina has higher gelatinization temperature which requires longer time to cook whereas foxtail millet and black gram dhal flour has lower gelatinization temperature. Similar results were reported by Torres et al., (2006) and Aravind et al., (2012) where they found that cooking time of developed pigeon pea flour added pasta and resistant starch pasta were significantly lower than the wheat pasta. 
With regard to cooked weight, control and T1 showed the highest values $(51.55,53.2 \mathrm{~g})$. Addition of steamed foxtail millet significantly decreased the cooked weight of the samples (ranged from 36.40 to $41 \mathrm{~g}$ ) as compare to control $(51.55 \mathrm{~g})$. When black gram dhal flour was added to the composite mix flour, the cooked weight increased significantly when compared to steamed foxtail millet flour samples. Whereas, addition of fenugreek powder (T12, T13, T14) showed significant decrease in cooked weight (ranged from 35.33 to $38.53 \mathrm{~g} / 10 \mathrm{~g}$ ) compared to wheat semolina (51.55 g).

The cooking loss is commonly used as an indicator of cooked pasta quality. Low amounts of cooking loss indicate high pasta cooking quality (Del Nobile, 2005). Dick and Youngs (1988) considered that cooking loss of 7-10 per cent to be acceptable for dried pasta. In the present study cooking loss was significantly higher in foxtail millet vermicelli (from $10.20 \mathrm{~g} 100 \mathrm{~g}$ in $\mathrm{T} 9$ to $34.37 \mathrm{~g} / 100 \mathrm{~g}$ in T4) than the control $(7.20 \mathrm{~g} / 100 \mathrm{~g})$. Cooked volume of developed vermicelli ranged from $31.00 \mathrm{ml}$ (T1) to $37.0 \mathrm{ml}$ (T10), which was significantly lower than the control vermicelli $(47.33 \mathrm{ml})$. So, cooked weight and cooked volume both were significantly higher in control than foxtail millet vermicelli (Table 4). It was because of lack of gluten in the developed foxtail millet vermicelli. Sudha et al., (1998) reported similar findings in case of vermicelli prepared from finger millet incorporated into semolina. It is because of different types of ingredients used in preparation of developed foxtail millet vermicelli which does not contain gluten.

Use of processed foxtail millet flour in vermicelli showed an improvement in the vermicelli strands in terms of length, nonstarchy mouth coating and reduction in cooking time and cooking loss (Table 4). It also had acceptable sensory characteristics. This may be due to steaming, which leads to gelatinization of starch, after drying it leads to retrogradation of starch, which is not easily soluble in water (Bustos et al., 2011).

Fig.1 Preparation of foxtail millet flour

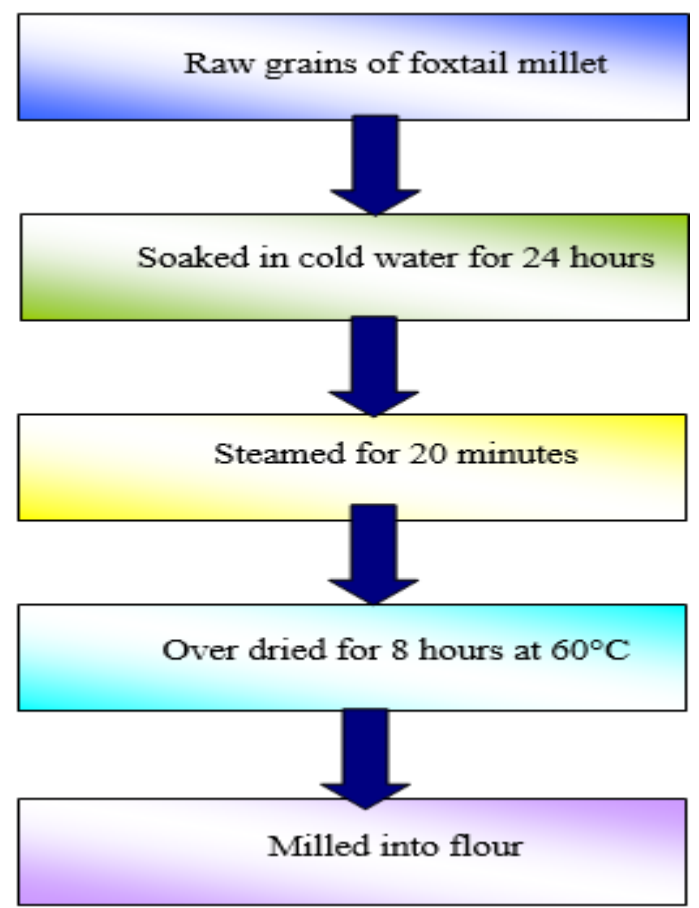


Fig.2 Preparation of fenugreek seed powder

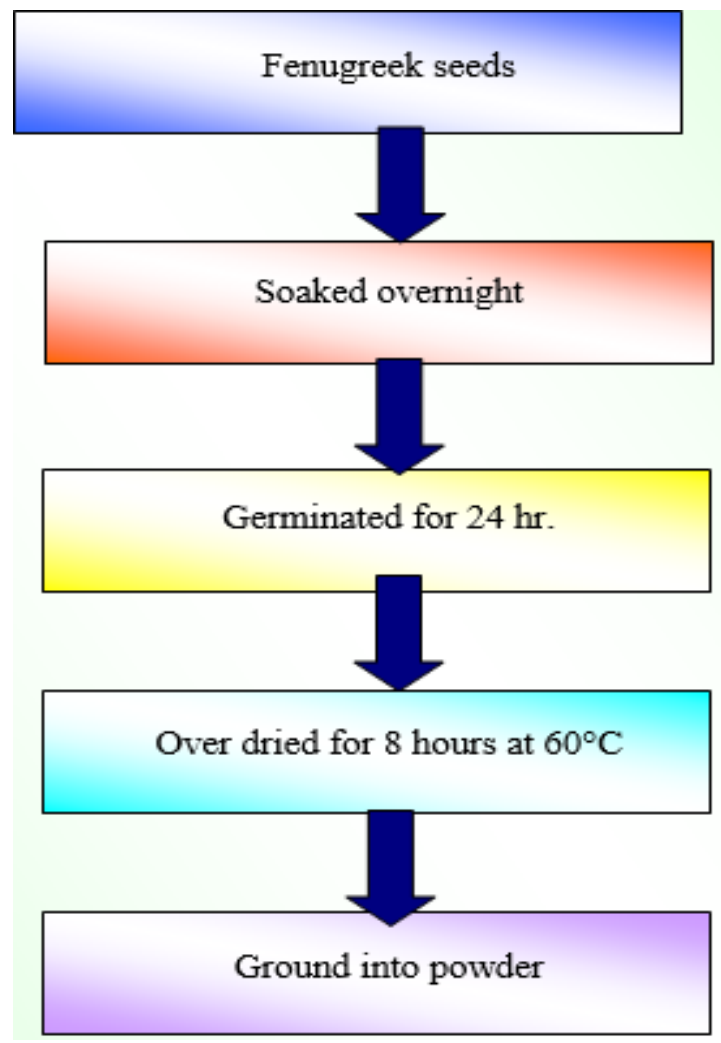

Fig.3 Flow chart for developed foxtail millet vermicelli

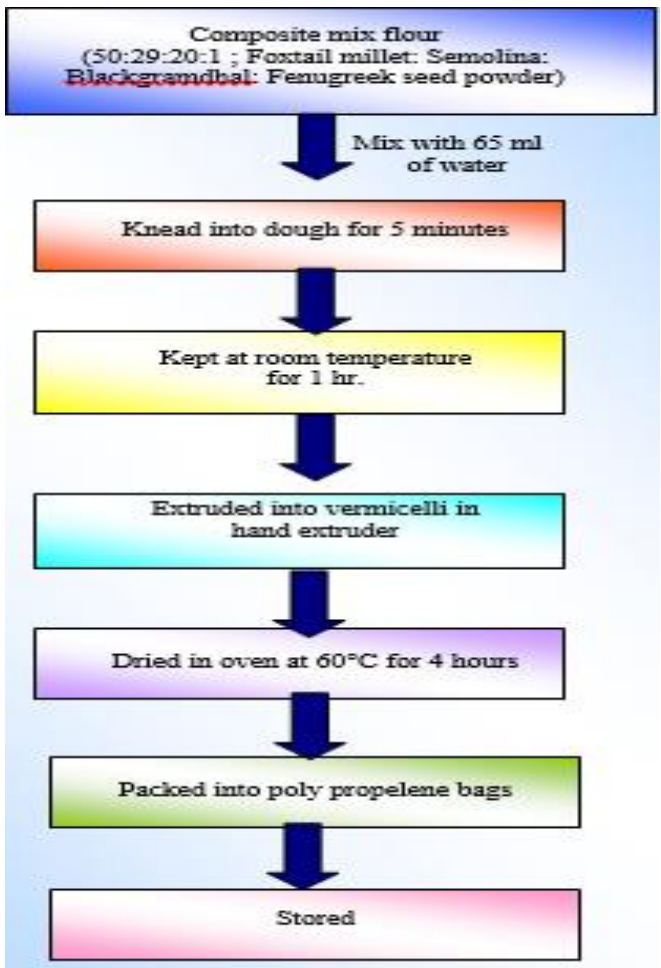


Fig.4 Influence of formulations on tensile strength of vermicelli

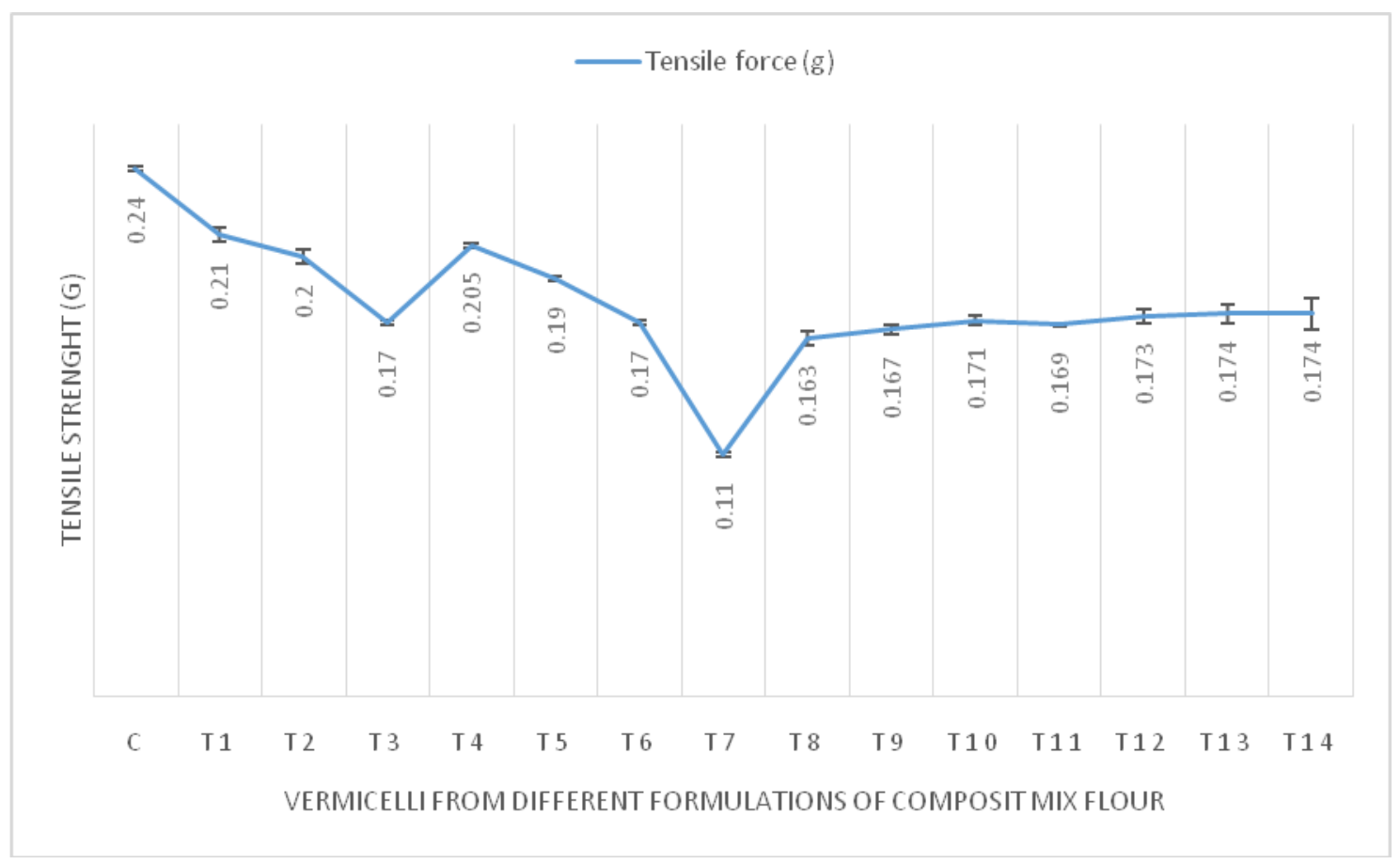

Fig.5 Influence of formulations on mechanical profile of vermicelli

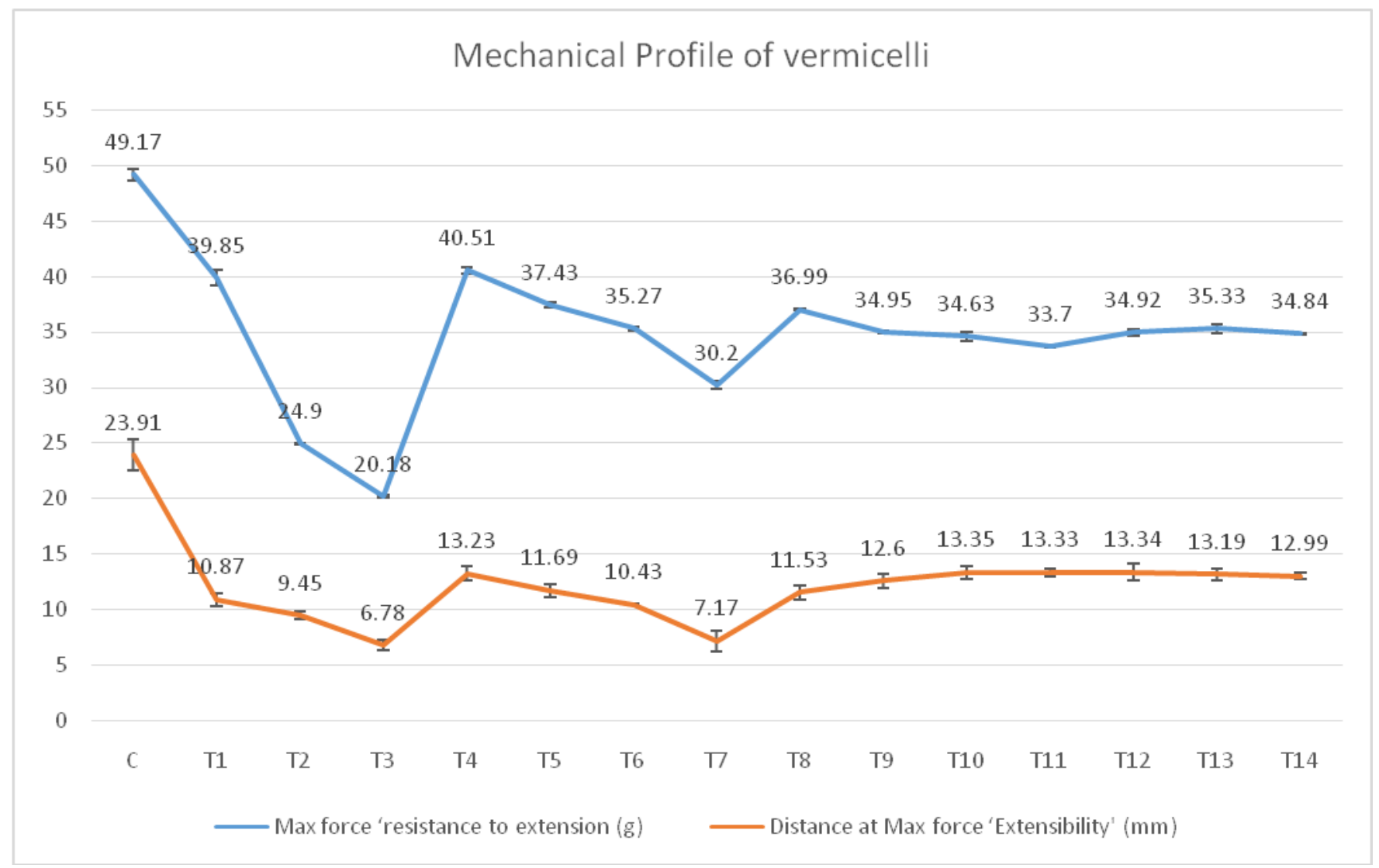


Fig.6 Influence of formulations on overall acceptability of vermicelli

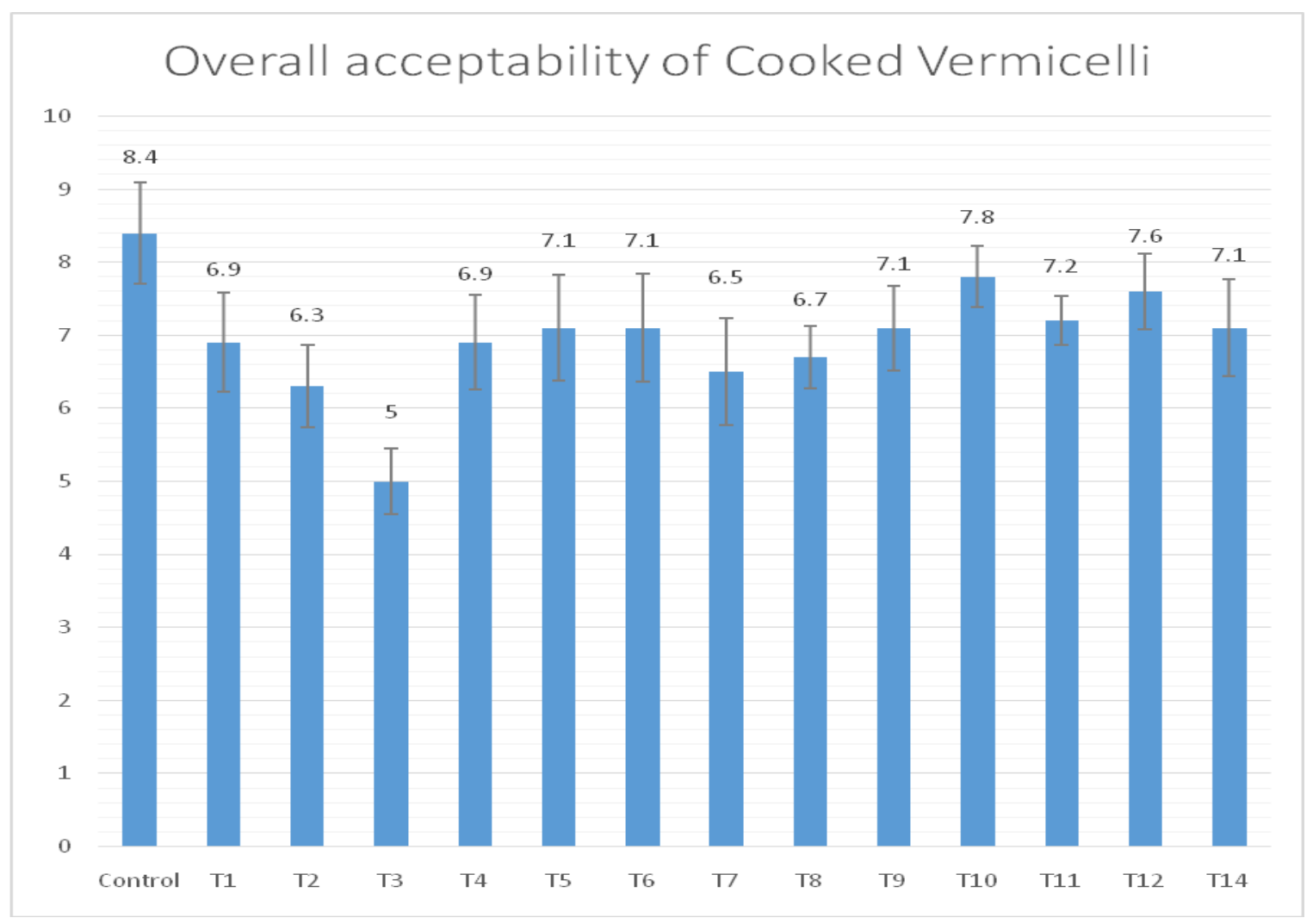

Table.1 Composition of different trials of vermicelli tried for optimization

\begin{tabular}{|c|c|c|c|c|c|}
\hline Sample & $\underset{(\%)}{\text { Semolina (S) }}$ & $\begin{array}{c}\text { Unprocessed } \\
\text { foxtail millet flour } \\
\text { (U) (\%) }\end{array}$ & $\begin{array}{c}\text { Steamed } \\
\text { foxtail millet } \\
\text { flour }(\mathbf{F}) \\
(\%)\end{array}$ & $\begin{array}{l}\text { Black gram dhal } \\
\text { flour (B) } \\
(\%)\end{array}$ & $\begin{array}{c}\text { Fenugreek } \\
\text { seed flour }(\mathrm{M}) \\
(\%)\end{array}$ \\
\hline $\mathrm{C}$ & 100 & ---- & ---- & ----- & ----- \\
\hline $\mathrm{T} 1$ & 80 & 20 & ---- & ---- & ---- \\
\hline $\mathrm{T} 2$ & 70 & 30 & --- & ----- & ---- \\
\hline $\mathrm{T} 3$ & 60 & 40 & $-\ldots$ & $-\ldots$ & $-\ldots$ \\
\hline $\mathrm{T} 4$ & 70 & $-\ldots$ & 30 & $-\ldots$ & $-\ldots$ \\
\hline $\mathrm{T} 5$ & 60 & ---- & 40 & ---- & ---- \\
\hline $\mathrm{T} 6$ & 50 & ---- & 50 & ---- & ---- \\
\hline $\mathrm{T} 7$ & 40 & ----- & 60 & ----- & ----- \\
\hline T8 & 40 & ---- & 50 & 10 & ---- \\
\hline T9 & 35 & --.- & 50 & 15 & ---- \\
\hline T10 & 30 & ---- & 50 & 20 & ---- \\
\hline $\mathrm{T} 11$ & 25 & ---- & 50 & 25 & ---- \\
\hline $\mathrm{T} 12$ & 29 & ---- & 50 & 20 & 1 \\
\hline T13 & 28 & ---- & 50 & 20 & 2 \\
\hline $\mathrm{T} 14$ & 27 & ---- & 50 & 20 & 3 \\
\hline
\end{tabular}


Table.2 Physical characteristics of foxtail millet and other ingredients used for Vermicelli development

\begin{tabular}{|l|c|c|c|}
\hline \multirow{2}{*}{\multicolumn{1}{|c|}{ Ingredients }} & \multicolumn{3}{|c|}{ Physical characteristics } \\
\cline { 2 - 4 } & Weight $(\mathbf{g})$ & Volume(ml) & Bulk Density $(\mathbf{g} / \mathbf{m l})$ \\
\hline Foxtail Millet & $2.39 \pm 0.03$ & $0.85 \pm 0.005$ & $2.81 \pm 0.003$ \\
\hline Black gram & $23.07 \pm 0.07$ & $11.30 \pm 0.003$ & $2.04 \pm 0.004$ \\
\hline Fenugreek Seed & $16.67 \pm 0.04$ & $11.07 \pm 0.004$ & $1.51 \pm 0.003$ \\
\hline
\end{tabular}

Results are Mean \pm SD of three determinations

Table.3 Physical and functional characteristics of flour used for vermicelli development (Mean \pm SD)

\begin{tabular}{|l|c|c|c|c|c|}
\hline \multicolumn{1}{|c|}{ Type of flour } & $\begin{array}{c}\text { Volume } \\
(\mathbf{m l} / \mathbf{g})\end{array}$ & $\begin{array}{c}\text { Density } \\
(\mathbf{g} / \mathbf{m l})\end{array}$ & $\begin{array}{c}\text { Water absorption } \\
\text { capacity }(\mathbf{m l} / \mathbf{g})\end{array}$ & $\begin{array}{c}\text { Swelling } \\
\text { power }(\mathbf{\%})\end{array}$ & $\begin{array}{c}\text { Percent } \\
\text { solubility }\end{array}$ \\
\hline Semolina & $1.04 \pm 0.01$ & $0.97 \pm 0.002$ & $0.80 \pm 0.01$ & $8.00 \pm 0.05$ & $30.53 \pm .11$ \\
\hline Black gram dhal & $1.02 \pm 0.01$ & $0.99 \pm 0.01$ & $0.48 \pm 0.05$ & $5.53 \pm 0.09$ & $21.53 \pm 1.5$ \\
\hline Foxtail millet & $1.04 \pm 0.01$ & $0.97 \pm 0.02$ & $0.50 \pm 0.01$ & $7.21 \pm 0.27$ & $22.36 \pm 0.49$ \\
\hline Fenugreek seed & $1.04 \pm 0.02$ & $0.97 \pm 0.01$ & $0.50 \pm 0.00$ & $8.91 \pm 0.13$ & $26.07 \pm 0.37$ \\
\hline 'F' value & 0.85 & 2.93 & 0.739 & 7.59 & 0.046 \\
\hline Sem \pm & 0.01 & 0.01 & 0.01 & 0.92 & 2.92 \\
\hline CD & $0.02^{*}$ & 0.96 & $0.30 *$ & $0 .{ }^{`} 1437 * *$ & $1.5 * *$ \\
\hline
\end{tabular}

*Significant at $5 \%$ level, ** Significant at $1 \%$ level, NS= Non significant

Values with the same letter are not significantly different

Table.4 Cooking quality of different trials of vermicelli (mean \pm S.D)

\begin{tabular}{|c|c|c|c|c|c|c|}
\hline & S: U: F:B:M & $\begin{array}{l}\text { Cooking time } \\
(\text { min) }\end{array}$ & $\begin{array}{c}\text { Cooked } \\
\text { weight }(g)\end{array}$ & $\begin{array}{c}\text { Cooking loss } \\
\text { (g/100g) }\end{array}$ & $\begin{array}{c}\text { Cooked } \\
\text { volume }(\mathbf{m l})\end{array}$ & $\begin{array}{l}\text { bulk density } \\
(\mathrm{g} / \mathrm{ml})\end{array}$ \\
\hline $\mathrm{C}$ & 100:0:0:0:0 & $6.90 \pm 0.36^{\mathrm{f}}$ & $51.55 \pm 0.51^{\mathrm{a}}$ & $7.20 \pm 0.10^{i}$ & $47.33 \pm 2.08^{\mathrm{a}}$ & $1.09 \pm 0.04^{\mathrm{gf}}$ \\
\hline $\mathrm{T} 1$ & 80:20:00:0:0 & $8.50 \pm 0.10^{\mathrm{h}}$ & $53.2 \pm 0.73^{\mathrm{a}}$ & $19.05 \pm 0.16^{d}$ & $34.00 \pm 1.00^{\text {cdef }}$ & $1.56 \pm 0.055^{b}$ \\
\hline $\mathrm{T} 2$ & $70: 30: 0: 0: 0$ & $8.20 \pm 0.20^{\mathrm{gh}}$ & $48.96 \pm 1.70^{b}$ & $23.03 \pm 0.03^{b}$ & $31.00 \pm 1.00^{\mathrm{g}}$ & $1.58 \pm 0.11^{b}$ \\
\hline $\mathrm{T} 3$ & 60:40:0:0:0 & $8.37 \pm 0.42^{\mathrm{h}}$ & $47.00 \pm 1.00^{\mathrm{b}}$ & $34.37 \pm 1.10^{\mathrm{a}}$ & $28.00 \pm 1.00^{\mathrm{h}}$ & $1.68 \pm 0.024^{\mathrm{a}}$ \\
\hline $\mathrm{T} 4$ & 70:0:30:0:0 & $8.20 \pm 0.20^{\mathrm{g}}$ & $41.00 \pm 1.00^{\mathrm{e}}$ & $17.24 \pm 0.21^{\mathrm{e}}$ & $36.00 \pm 1.00^{\mathrm{bc}}$ & $1.14 \pm 0.00^{\text {gfed }}$ \\
\hline $\mathrm{T} 5$ & 60:0:40:0:0 & $7.17 \pm 0.153^{f}$ & $38.00 \pm 1.00^{f}$ & $18.34 \pm 0.51^{d}$ & $31.67 \pm 0.58^{\mathrm{fg}}$ & $1.20 \pm 0.02^{\mathrm{d}}$ \\
\hline T6 & 50:0:50:0:0 & $6.17 \pm 0.15^{\mathrm{e}}$ & $38.67 \pm 0.58^{f}$ & $18.87 \pm 0.45^{\mathrm{d}}$ & $35.33 \pm 0.58^{\mathrm{bcd}}$ & $1.09 \pm 0.02^{\mathrm{gfe}}$ \\
\hline $\mathrm{T} 7$ & 40:0:60:0:0 & $5.25 \pm 0.25^{\mathrm{d}}$ & $36.40 \pm 0.53^{\mathrm{gf}}$ & $21.97 \pm 1.19^{c}$ & $32.53 \pm 0.50^{\mathrm{efg}}$ & $1.12 \pm 0.01^{\text {gfed }}$ \\
\hline $\mathrm{T} 8$ & $40: 0: 50: 10: 0$ & $4.53 \pm 0.058^{\mathrm{ab}}$ & $41.00 \pm 0.87^{\mathrm{e}}$ & $16.89 \pm 0.34^{\mathrm{e}}$ & $36.10 \pm 0.82^{b c}$ & $1.14 \pm 0.05^{\text {gfed }}$ \\
\hline T9 & $35: 0: 50: 15: 0$ & $4.34 \pm 0.14^{\mathrm{a}}$ & $42.40 \pm 0.34^{\mathrm{ed}}$ & $10.20 \pm 0.10^{h}$ & $36.67 \pm 0.58^{b}$ & $1.16 \pm 0.011^{\text {fed }}$ \\
\hline T10 & $30: 0: 50: 20: 0$ & $4.73 \pm 0.25^{\mathrm{bc}}$ & $43.33 \pm 1.53^{\mathrm{d}}$ & $12.40 \pm 0.56^{\mathrm{g}}$ & $37.00 \pm 1.00^{\mathrm{b}}$ & $1.17 \pm 0.07^{\text {fed }}$ \\
\hline T11 & $25: 0: 50: 25: 0$ & $5.07 \pm 0.06^{\mathrm{cd}}$ & $36.33 \pm 0.58^{\mathrm{gf}}$ & $15.60 \pm 0.36^{\mathrm{f}}$ & $30.94 \pm 0.83^{\mathrm{g}}$ & $1.17 \pm 0.03^{\text {ed }}$ \\
\hline $\mathrm{T} 12$ & $29: 0: 50: 20: 1$ & $5.03 \pm 0.03^{\mathrm{cd}}$ & $35.33 \pm 3.05^{\mathrm{g}}$ & $10.27 \pm 0.04^{h}$ & $33.00 \pm 3.61^{\text {defg }}$ & $1.07 \pm 0.027^{\mathrm{g}}$ \\
\hline T13 & $28: 0: 50: 20: 2$ & $5.10 \pm 0.10^{\text {cd }}$ & $36.73 \pm 2.05^{\mathrm{gf}}$ & $10.85 \pm 0.67^{\mathrm{h}}$ & $34.67 \pm 1.53^{\text {bcde }}$ & $1.06 \pm 0.05^{\mathrm{g}}$ \\
\hline \multirow[t]{3}{*}{ T14 } & $27: 0: 50: 20: 3$ & $5.13 \pm 0.15^{\mathrm{d}}$ & $38.53 \pm 1.56^{\mathrm{f}}$ & $10.69 \pm 0.51^{\mathrm{h}}$ & $36.00 \pm 1.00^{\mathrm{bc}}$ & $1.07 \pm 0.02^{\mathrm{g}}$ \\
\hline & F value & $170.36^{* *}$ & $56.24 * *$ & $474.4 * *$ & $29.777 * *$ & $63.6^{* *}$ \\
\hline & $\mathrm{CD}$ & 4.71 & 27.29 & 10.71 & 29.80 & 0.92 \\
\hline
\end{tabular}

*Significant at $5 \%$ level, ** significant at $1 \%$ level, Values with the same letter are not significantly different WS- Wheat Semolina; UFMF -Unprocessed Foxtail Millet Flour; SFMF -Steamed Foxtail Millet Flour; BF- Black gram dhal flour; WS- Wheat Semolina; FSP- Fenugreek Seed Powder 
Further addition of black gram dal flour (upto $20 \%$ ) improved the dough characteristics, cooking quality in terms of cooking time and cooking loss and bulk density.

Decrease in cooking loss in black gram dhal incorporated vermicelli may be attributed to the structural changes in the protein network by foxtail millet and black gram dhal (Madhumitha et al., 2011).

Addition of black gram dhal improved the cooking quality, this may be due to presence of higher protein and sticky and gummy characteristics of black gram dal.

Bulk density of foxtail millet vermicelli prepared with addition of fenugreek seed powder (at 1, 2 and $3 \%$ level) $1.07 \mathrm{~g} / \mathrm{ml}$ was on par control vermicelli $(1.09 \mathrm{~g} / \mathrm{ml})$. Significantly, higher bulk density was noted in $\mathrm{T} 2(1.58 \mathrm{~g} / \mathrm{ml})$.

All the functional and cooking quality parameters were lower in the developed millet vermicelli. The bulk density of vermicelli from millet blend was significantly higher and cooked volume was lower as compared to the control. Camire and King (1991) reported that sample with lower bulk density had larger expansion ratio which stands true in our study. The decrease in expansion ratio was because of increase in protein form black gram dal added into the vermicelli. Similar observation were made by Balasubramanian and Singh (2007) who reported that the decrease in expansion of extrudates with increase in level of different legumes such as chickpea, green gram and black gram. Singh et al., (2006) reported lower expansion ratio in soy-kodo blends than the wheat pasta.

\section{Texture analysis of vermicelli}

Texture analysis of vermicelli prepared with different combinations of flour was evaluated for its breaking strength and extensibility is presented in Figures 4 and 5.

The control sample $\mathrm{C} 1$ required highest tensile force (49.17 g) for breaking (Fig. 5). For samples T1, T2 and T3 maximum force to break, the raw vermicelli strands varied from $10.87 \mathrm{~g}$ (20\% level) to $24.90 \mathrm{~g}$ (30\% level). However, when steamed foxtail millet flour was incorporated in vermicelli (sample T4, T5, T6 and T7) the breaking strength increased as compared to unprocessed foxtail millet vermicelli (T1, T2 and T3). It was because of partial gelatinization of foxtail millet flour, which contributed to its breaking strength. As the level of steamed foxtail millet flour was increased from 30 to 60 per cent the (T4 to T7) max force required for breaking decreased from $40.51 \mathrm{~g}$ to $30.20 \mathrm{~g}$. It was because the gluten content was also decreased gradually and gluten is main component which provides strength and integrity to vermicelli strands. Further the max force required to break vermicelli decreased from 36.99 to 33.7 , with increased incorporation of black gram dhal (T8, T9, T10 and T11). With addition of fenugreek seed powder at different level $(1,2,3 \%)$, no significant difference was observed for tensile force and maximum force resistance to extension.

The similar trend was observed when texture was analyzed in terms of extensibility. The control vermicelli had the highest distance $(23.91 \mathrm{~mm})$. With increased incorporation of unprocessed foxtail millet flour, extensibility decreased from $10.87 \mathrm{~mm}$ (T1) - $6.78 \mathrm{~mm}$ (T3). Similar trend was observed in case of incorporation of steamed foxtail millet flour [from 13.23 (T4) to $7.17 \mathrm{~mm}$ (T7)].

Extensibility increased significantly with addition of black gram dhal from 10 (T8) to 20 (T10) percent because of adhesive property of black gram dhal. Addition of fenugreek seed powder had no significant 
effect on extensibility because of its minute proportion in the composite mix flour.

In short, the breaking strength and extensibility (Fig. 5) was highest in case of control (C), when different functional ingredients were added at different levels the strength of the strands and extensibility reduced significantly, it was because of lack of gluten in composite mix flour and gluten has elasticity and strength, which shows the higher breaking strength. With decrease in the semolina in composite mix flour, the breaking strength decreased. Similarly, Mridula et al., (2008) have noted a gradual decrease in peak breaking force, breaking energy with increase in the level of sorghum flour into the noodles. Reungmaneepaitoon et al., (2007) found that tensile force and breaking distance of noodles decreased as rice flour content increased.

\section{Overall acceptability of cooked vermicelli:}

Sensory evaluation of vermicelli revealed that T12 vermicelli from 30:50:20 ratio of S, F, B and FMF was liked very much after control vermicelli, obtained score of 7.8 on the 9 point Hedonic scale (Fig. 6). The mean overall score of developed noodles from composite flour was in the range of highly acceptable criteria (7-9). Results indicated that semolina could be replaced to an extent of 70 per cent with foxtail millet flour and black gram flour (Fig. 3) without affecting the sensory quality of vermicelli.

Foxtail millet could be successfully incorporated in extrusion cooking of cereal processing to prepare ready to eat products such as vermicelli and other pasta products whose demand is increasing rapidly throughout the world. A $50 \%$ blend of foxtail millet with 20 per cent black gram flour and 1 percent fenugreek seed powder was most efficiently used in the vermicelli formulation. This developed vermicelli was highly acceptable and could be a healthy snack food for people of all age group.

\section{References}

Aravind N., Christopher, M., Blazek, J., and Elliot, P. G., 2012, Optimisation of resistant starch II and III levels in durum wheat pasta to reduce in vitro digestibility while maintaining processing and sensory characteristics. Food Chem., 136: 11001109.

Austin, A. and Ram, A., 1971, Studies on chapatti-making quality of wheat. Indian Council of Agricultural Research: New Delhi. TechBull. (Agri), 31. 105-108.

Balasubramanian, K. and Vishwanathan, P, 2010, Carbohydrate composition of finger millet (Eleusine coracana) and foxtail millet (Setaria italica). Quanl Plant Plant Food Hum Nutr 28(4):293-303

Balasubramanian, S. and Singh, N., 2007, Effect of extrusion process variables and legumes on corn extrudates behaviour. J. Food Sci. Tech., 44(3): 330-333.

Bustos M. C., Perez G. T. and León A. E., 2011, Sensory and nutritional attributes of fibreenriched pasta. Food Sci. Tech., 44: 14291434.

Camire, M.E. and King, C.C., 1991, Protein and fibre supplementation effects on extruded corn meal snack quality. J. Food Sci., 56: 760-763.

Del Nobile, M.A., Baiano, A., Conte, A., and Mocci, G., 2005, Influence of protein content on spaghetti cooking quality. J. Cereal Sci., 41: 347-356.

Dick, J. W., and Youngs, V.L., 1988, Evaluation of durum wheat semolina and pasta in the United States, In: Fabriani, G., Lintas, C.editors, Durum wheat: Chemistry and Technology, St. Paul, M.N: American Association of Cereal Chemists, pp. 237248.

International Crops Research Institute for the Semi-Arid Tropics (ICRISAT)/Food and Agriculture Organization (FAO), 1996. The World Sorghum and Millet Economies. ICRISAT, Patancheru, India/ FAO, Rome.

Kotagi K, Chimmad B, Naik RK, Kamatar MY. 
Nutrient enrichment of little millet (Panicum miliare) flakes with garden cress seeds. International Journal of Food and Nutritional Sciences 2013; 2(3):36-39.

Madhumitha, S., Prabhasankar P. and Jyotsana R., 2011, Influence of additives on functional and nutritional quality characteristics of black gram flour incorporated pasta. J. Texture Studies, 42: 441450.

Meghana, D. R., Saraswathi, G. and Premavalli, K. S., 2011, Effect of supplementation of ragi based snacks on nutritional status of children. NAIP: National symposium recapturing nutritious millets for health and management of diseases, UAS, Dharwad, Dec 16 to 17, PP-35.

Mridula, D., Gupta, R. K. and Jain, R., 2008. Effect of sorghum flour on quality of noodles. Indian J. Nutri. Dietet., 45: 138145.

Pradeep SR and Guha M (2011). Effect of processing methods on the nutraceutical and antioxidant properties of little millet (Panicum sumatrense) extracts. Food Chemistry, 126: 1643-1647.

Radhika G, Sathya RM, Ganesan A, Saroja R, Vijayalakshmi P and Sudha A. Dietary Profile of Urban Adult Population in South India in the Context of Chronic Disease Epidemiology (CURES-68). J. Public Health Nut. 2011; 14(4): 591-598.

Rao, B.R., Nagasampige, M.H., and Ravikiran, M. (2011). Evaluation of nutraceutical properties of selected small millets. J. Pharm.Bio.Allied.Sci. 3, 277-279. doi:10.4103/0975-7406.80775

Reungmaneepaitoon, S., Sikkhamondhol, C., Jariyavattanavijit, C., and Teangpook, C., 2007, Development of instant noodles from high-iron rice and iron-fortified rice flour. In. Food Res. Product Dev., 30 (6): 713-721
Schoch, T. J. 1969. Starch in foods. Pages 395420: Symposium on foods: Carbohydrates and their Roles. H. W. Schultz, R. F. Cain, and R. W. Wrolstad, eds. Avi Publishing Co.: Westport, CT.

Singh, P. and Raghuvanshi, R.S. Finger Millet for Food and Nutrition Security. African Journal of Food Science. 2012; 6(4): 77-84.

Singh, D. S., Garg, S. K., Singh, M. and Goyal, N. 2006, Effect of major processing parameters on the quality of extrudates made out of soy-kodo blends. J. Food Sci. Technol. 43(4): 434-437.

Sudha, M. L., Vetrimani, R. and Rahim, A. 1998, Quality of vermicelli from finger millet (Elusine coracana) and its blend with different milled wheat. Food Research International 31(2):99-104

Torres, A., Frias, J., Granito, M.and VidalValverde, C., 2006, Germinated Cajanus cajan seeds as ingredients in pasta products: Chemical, biological and sensory evaluation. Food Chem., 101: 202-211.

Williams, P. C., Nakoul, H., and Singh, K. B., 1983, Relationship between cooking time and some physical characteristics in chickpea (Cicer arietinum L.). J. Sci. Food Agri. 34: 492-496.

Yang X, Wan Z, Perry L, Lu H, Wang Q, Hao C, Li J, Xie F, Yu J, Cui T, Wang T, Li M \& Ge QH. Early Millet Use in Northern China. Proc. Nat. Acad. Sci. 2012; USA. pp. 1-5.

Yenagi NB (2007) Value adding strategies for production and sustainable use of indigenous small millets. In: KT Krishne Gowda and A Seetharam (Eds.). Food uses of small millets and avenues for further processing and value addition. AICRP, Bangalore. Pp 40-47.

\section{How to cite this article:}

Pragya Pandey, Usha Malagi, Nirmala Yenagi and Pushpa Dhami. 2017. Evaluation of Physico-Functional, Cooking and Textural Quality Characteristics of Foxtail Millet (Setaria italica) Based Vermicelli. Int.J.Curr.Microbiol.App.Sci. 6(10): 1323-1335.

doi: https://doi.org/10.20546/ijcmas.2017.610.156 